\title{
Gender-Labeling of Children's Books and Reading Preferences as Represented through the KidLitosphere
}

\author{
Emily Seitz
}

\begin{abstract}
This article discusses a qualitative study conducted as part of a dissertation on gendered literacy. The findings are based on sampling and analysis of data drawn from 23 blogs that are part of the KidLitosphere, a website aggregating blogs dealing with children's literature. It discusses the primary findings relating to the genderlabeling of children's books, including 1) bloggers' and commenters' direct labeling of books as "girl"- and "boy"-preferred; 2) educators' expectations of boys' reading preferences; 3) bloggers' and commenters' consistently mentioning certain books and/or series, coded "iconic boy books," in reference to boys' reading; and, 4) educators' expectation that boys prefer male protagonists and girls prefer female protagonists. It also discusses resistance to these themes in the form of 1) bloggers' and commenters' speaking directly against the labeling of books as "girl"- and "boy"preferred; 2) bloggers' and commenters' expressing the belief that a child's sex should not influence the child's reading preferences; and, 3) educators' not expecting girls to prefer what are perceived to be "girl"-preferred texts, or boys to prefer "boy"-preferred texts.
\end{abstract}

Keywords: blog, gender, KidLitosphere, literacy, reading

\section{Introduction}

This paper is based on a dissertation observing conceptions of gendered literacy as represented through blog narratives. Scholars have used the term "gendered literacy" to describe attitudes toward literacy and behaviors they have observed through empirical research. Therefore, the phenomenon known as "gendered literacy" has been discussed from many different angles; however, the scholarship to date has not produced a complete conceptual model of gendered literacy. For example, Orellana (1995) presents "gendered literacy" as a concept relating to gendered texts produced by children in the classroom. Like Orellana (1995), Sanford (2005/2006) and Bausch (2014) (who focuses on boys' literacy) present students' production of gendered texts as a function of "gendered literacy." However, Sanford also examines "gendered literacy" in relation to teachers' perceptions of students' enjoyment of reading (girls enjoyed reading, but boys did not), and of students' attitudes toward school and the reading of textbooks (girls had more positive attitudes toward school than boys and enjoyed reading textbooks more than boys).

This article first discusses the understandings of "gender" and "literacy" underpinning the study (within the U.S. and other Western contexts) and the literature relating to "gendered literacy" from previous studies. It then describes gendered literacy as it was observed through narratives sampled from 23 blogs that are part of the 
KidLitosphere, a website aggregating over 550 blogs treating various aspects of children's and young adult literature. The paper describes the main findings of the dissertation study relating to the gender-labeling of books for young people, including direct labeling of books as "boy"- and "girl"-preferred; educators' alignment of boys' reading preferences according to traditional notions of boys' reading preferences; and, the consistent mention of certain books and/or series, coded "iconic boy books," in reference to boys' reading.

\section{Theoretical Framework}

For the purpose of the study, gender is understood as a socially-constructed phenomenon, which children learn as they grow into adulthood. Such an understanding of gender is informed by the work of Bem (1993), who describes gender as a kind of cultural knowledge that children learn through social practices. Bem perceives that children are not passive recipients of cultural knowledge of gender; rather, they are constantly both taking on and constructing meanings about gender through "culturally significant social" practices (pp. 140-141). The study discussed in this paper approaches literacy as one such "culturally significant social practice" through which gendered meanings are formed.

Similar to the understanding of gender, for the purpose of this study, literacy is understood to be a social phenomenon, and literacy is learned through social practice (Gilbert, 2003; Long, 2003; Millard, 2003; Orellana, 1995; Vygotsky, 1978). A broad definition of literacy as the reading, writing, and creation of a diversity of texts informed this study (i.e. Smith \& Wilhelm, 2002). However, the literacy practice mentioned most frequently in the blog narratives sampled and analyzed for the study was the reading of traditional print books.

For the most part, gendered literacy has been conceived as the association of literacy (particularly school-based literacy) with femininity. Millard (1994), for instance, states that "in Western societies, reading is presented largely as a girl-preferred activity" (p. 96). Rowan, Knobel, Bigum, and Lankshear (2002) describe the association of literacy with femininity in the developed world as linked to the predominance of female schoolteachers (p. 40). Likewise, other scholars have documented the rise of women in terms of representation among schoolteachers (i.e., Conway, 1974; Hansot \& Tyack, 1988; Monaghan, 1994) and also as authors of story-focused primers (Monaghan, 1994).

\section{Literature Review}

The relationship between gender and literacy has been described according to the following themes:

1. Gendered literacy as performed by multiple actors, including children and young adults, literacy educators, and those in the publishing industry.

Studies relating to this aspect span more than 20 years of scholarship and treat children's gendered reading preferences and approaches to literacy. The majority of these studies have taken place within the school setting (i.e. Bausch, 2014; Chapman, Filipenko, McTavish, \& Shapiro, 2007; Maynard, 2002; Millard, 1997, 2003; Moss, 2007; Orellana, 1995; Smith \& Wilhelm, 2002). In contrast, the study described in this article analyzes blog data as a site in which to encounter young people's reading experiences and perceptions of 
those experiences outside of school, and the blogs represent a naturalistic setting in which to gather data.

The studies suggest that girls and boys tend to read and write differently and assume differing relationships to school-based literacy activities. In this sense, researchers perceive children as enacting a gendered literacy - that is, exhibiting differing literacy practices according to gender and behaving in ways that are interpreted as genderstereotypical. Review of the literature reveals two salient ways in which researchers portray children's enactment of gendered literacy: 1) through boys' resistance to formal, school-based literacy in comparison to girls' more enthusiastic adoption of formal literacy practice; and, 2) through girls' and boys' differing literacy preferences.

Although it is often claimed that the children's publishing industry is femaledominated, statistics are scarce. However, an analysis by VIDA: Women in Literary Arts organization (2014) tallying numbers of female versus male authors of children's and young adult literature among winners of book awards found that female authors were prominent, and so it seems there is a basis for such claims, at least in terms of author recognition.

2. Gendered literacy as a quantifiable achievement gap between male and female students.

This strand of research points to differences between boys and girls in terms of achievement measured through test scores. For example, for the reading assessment that is part of the National Assessment of Educational Progress, informally known as the "Nation's Report Card" for the United States, an achievement gap in reading between girls and boys has been consistent and measured over time since 1971. And, on the Organisation for Economic Co-Operation and Development's (OECD) Programme for International Student Assessment (PISA) in 2012, the results for approximately 510,000 students in 65 countries and economies showed that, "on average across OECD countries, girls outperform boys in reading by 38 score points" (Organisation for Economic Co-operation and Development, 2014, p. 199).

3. Gendered literacy as the result of biologically-based cognitive differences between males and females.

This trend includes popular works (i.e. Gurian, 2011; Sax, 2005) marketed toward educators, which, drawing from research in neuroscience, favor a biological determinist approach to cognitive differences between males and females. Such works exaggerate these female/male differences and also use the differences to explain gendered behavioral differences.

4. Gendered literacy as the remnant of the historically gendered educational system (in the U.S.).

This scholarship follows two main themes: 1) the feminization of the teaching profession and 2) a historical pattern of boys' under-achievement. In terms of the feminization of the teaching profession, according to Monaghan (1994), in the U.S. for much of the $19^{\text {th }}$ and 
20th centuries, women dominated the elementary school teaching profession (p. 30). Women also were the main authors of elementary primers (Monaghan, p. 32). Regarding a legacy of boys' under-achievement, Hansot and Tyack (1988) cite evidence showing that by the mid-19th century in the U.S., in coeducational school environments, girls proportionally received higher grades than boys; girls were more likely than boys to be promoted to the next grade; and more girls continued on to high school (p.758).

The studies discussed briefly above address the gendered dimensions of literacy practice that children learn as they become literate, particularly within the school context. However, individually they do not present a summary of what gendered literacy is, and they only scratch the surface as to gendered literacy as a cultural practice is maintained.

Blogs included in the KidLitosphere, a website bringing together blogs relating to children's and young adult literature (especially reviews), were chosen as the setting in which to observe the social performance of gendered literacy. The KidLitosphere is an important site in that it represents a social networking space within the blogosphere for people whose primary work and/or recreation center around literature for children and young adults.

\section{Research Questions}

Four research questions guided this study:

- Research Question 1: What are the conceptions of gendered literacy among literacy educators (parents, public librarians, school librarians, and teachers); creators of texts for children (published authors, editors, and published illustrators); and, children/young adults, as represented in their blogging activities?

- Research Question 2: How do the conceptions of gendered literacy identified through the blogging activities of literacy educators, creators of texts for children, and children/young adults compare to the theoretical conceptions identified in the literature review?

- Research Question 3: What similarities and differences, if any, are represented in conceptions of gendered literacy among literacy educators; creators of texts for children; and, children/young adults, as represented in their blogging activities?

- Research Question 4: What patterns, if any, of resistance to the dominant conceptions of gendered literacy may be found among the blog posts analyzed?

\section{Methodology}

A review of the previous scholarship determined the groups to be studied: literacy educators (parents, public librarians, school librarians, and teachers); creators of texts for children (published authors, editors, and published illustrators); and, children/young adults. The KidLitosphere was chosen as the site of the study for two reasons: 1) the KidLitosphere represents a natural setting in which themes of gender and literacy are prevalent; and 2) the bloggers contributing to the KidLitosphere include all the perspectives of interest.

This qualitative study takes the approach referred to by Lincoln and Guba (1985) as naturalistic inquiry, the principles of which include the use of a human instrument in the 
investigation of a natural setting; purposive sampling; emergent study design; inductive data analysis; and tentative application of the study's results (pp. 39-43). Twenty-three blogs were selected for analysis from the KidLitosphere. In choosing these twenty-three blogs, representativeness of the groups of interest was a consideration, along with including blogs authored by key participants in the 2012 KidLitosphere conference (attended by the principal investigator). For example, one of the blogs from which data were sampled was by the conference organizer, the head of youth materials selection for a large public library system in the U.S. Other blogs selected for sampling included a conference panelist's blog, a blog that was mentioned as frequently read by conference panelists, as well as blogs listed on the blogrolls of blogs that had already been selected for sampling.

Blogs also had to have been updated within the past month at the start date of data collection (January 2, 2013) and yield meaningful results (that is, relating to the conceptual model of gendered literacy introduced in the literature review; or presenting new or resistant dimensions of it) when searched with the keyword search, "boy girl read." Blog posts and comments were then sampled from those blogs using the keyword search, "boy girl read." For two blogs, when a search of "boy girl read" yielded no results, the search terms were truncated to "boy" and "girl," and two separate searches were conducted (in these cases, using "read" as a separate search term retrieved too many results to be useful). In the case of one blog, no search function existed within the blog itself, and so blog posts and associated comments were collected by scrolling through the blog page by page doing separate searches on "boy," "girl," and "read" for each page. Data were analyzed inductively using the constant comparison method (Glaser \& Strauss, 1967) to identify themes, which were then coded to facilitate analysis. Because this was a naturalistic study, conclusions made based on the findings are limited in scope. However, the study provides a rendering of the KidLitosphere context through detailed data description, with the goal of facilitating transferability to research in other social contexts. The findings are trustworthy in that the data analyzed, quoted extensively in the reporting of the study results, present the phenomenon of study - gendered reading - from the perspective of the bloggers and commenters.

This study is limited in its focus on blogs, which are only one sociocultural site in which gendered literacy may be observed, and in the fact that blog narratives represent an often indirect sociocultural view of gendered literacy - for example, the bloggers' commentary more often reviews literature for young people than directly discusses literacy as gendered. However, qualitative content analysis of blog posts allowed for unobtrusive study of gendered literacy and the examination of multiple perspectives. Interviews with individual bloggers and one author outside the KidLitosphere were also used to triangulate data sources. 


\section{Types of Bloggers Represented Among the Blogs Selected for Sampling:}

Blog Blogger Type

B1 Child (F)

B2 Young adult (F)

B3 Public Librarian, Youth Services (M)

B4 Parent (F), editor (but not of children's books)

B5 Teacher $(\mathrm{F})$

B6 Teacher (M)

B7 Public Librarian, Youth Services (F)

B8 Public Librarian, Youth Services (M)

B9 School Librarian (F)

B10 School Librarian (M)

B11 Parent (F)

B12 Parent (M)

B13 Parent (M)

B14 Author (F)

B15 Author (M)

B16 Illustrator (F)

B17 Illustrator (M)

B18 Author/Illustrator (M)

B19 Editor (F)

B20 Book Designer/Editor (M)

B21 Blog of a well-known literary magazine focused on reviews of children's literature; includes posts by the editor

B22 Public librarian (F, without MLS; however, in data analysis - treated as a librarian); library consultant; mother of 2 sons

B23 Academic librarian (F, without MLS; however, in data analysis - treated as a librarian)

The following are coding examples for the claims made regarding the dissertation findings that are discussed in this article:

\begin{tabular}{|c|c|}
\hline Claim/Sub-Claim & Example from the Data \\
\hline Educators label books as "girl" and "boy"-preferred. & $\begin{array}{l}\text { B4 (2010): "Put him near any new books, even ones for } \\
\text { his sister, and he practitcally (sic) starts twitching with } \\
\text { anticipation of getting his hands on them." (parent, F) }\end{array}$ \\
\hline $\begin{array}{l}\text { Educators align boys' reading preferences with the } \\
\text { following: stories with male protagonists, comics, graphic } \\
\text { novels, science fiction, adventure, non-fiction, sports, } \\
\text { fantasy, gross humor, stories featuring vehicles, and } \\
\text { magazines. }\end{array}$ & $\begin{array}{l}\text { B3 (2010): "Why is it cool for boys to read realistic } \\
\text { fiction--books with no aliens or magicians, no world- } \\
\text { dominating villains, and nothing blows up?" (librarian, } \\
\text { M) }\end{array}$ \\
\hline $\begin{array}{l}\text { Bloggers and commenters consistently mention certain } \\
\text { book series, coded "iconic boy books," in reference to } \\
\text { boys' reading. }\end{array}$ & $\begin{array}{l}\text { B3 (2008): "What books would you recommend for } \\
\text { boys?...there are some great series out there. On one } \\
\text { extreme, easy to read and extremely funny are the } \\
\text { Captain Underpants books." (author, F, in response to a } \\
\text { question posed by a male librarian) }\end{array}$ \\
\hline
\end{tabular}




\section{Findings}

The most prominent findings relate to the gender- labeling of children's books. This gender-labeling is manifested in four main ways: 1) bloggers' and commenters' direct labeling of books as "girl"- and "boy"-preferred; 2) educators' expectations of boys' reading preferences; and, 3) bloggers' and commenters' consistently mentioning certain books and/or series, coded "iconic boy books," in reference to boys' reading; and, 4) educators' expectation that boys prefer male protagonists and girls prefer female protagonists. Resistance to gender-labeling of children's books was, however, also important among the data sampled. Resistance took the following forms: 1) bloggers' and commenters' speaking directly against the labeling of books as "girl"- and "boy"- preferred; 2) bloggers' and commenters' expressing the belief that a child's sex should not influence the child's reading preferences; and, 3) educators' not expecting girls to prefer what are perceived to be "girl"preferred texts, or boys to prefer "boy"-preferred texts.

\section{Gender-Labeling of Children's Books}

Bloggers' and commenters' labeling of books as "girl"- and "boy"-preferred (72 examples). Among those engaged in labeling, comments by librarians and parents were represented the most, followed by teachers, authors, and children/young adults. Overall, 31 examples refer to "boy" books, 25 to "girl" books, and 16 to both "girl" and "boy" books.

A female public librarian refers to a "boy" book as follows:

On the funny side, I've brought book one in the series Nathan Abercrombie, Accidental Zombie, by David Lubar....David Lubar is the guy who wrote the Weenies books, which, if you were a 9-year-old boy, might be all you needed to hear. (B22, 2010)

The librarian labels "a 9-year-old boy" as the typical audience for this book and a series by the same author. The direct labeling used here as a presumed aid to reader's advisory is found in several other examples. One example by B6 blogger, a male teacher, directly invites girls to read a book he has just reviewed $(B 6,2010)$. As in the previous example, the label is offered in the context of reader's advisory. The teacher labels the book for girls and also directly addresses "girls" as the book's perceived ideal audience.

In the following example a mother, also a homeschooler and previously a classroom teacher, comments on a request for reading suggestions for a girl, and, in doing so, refers to both "boy" and "girl" books:

She might try Cynthia Rylant's Cobble Street Cousins. Girly, but with different types of girls. Also, since she's into books that are traditionally "boy" books, my son went from Fly Guy right into Dav Pilkey's Ricky Ricotta series and those were the books that really catapulted him into reading independently this year. Another traditionally "boy" series she might enjoy is Nate the Great and that's not such a big leap from Fly Guy. (B4, 2010)

Although the mother, engaging in reader's advisory as in the previous examples, recommends "boy" books for a girl, she still makes a strict demarcation between "girl" and "boy" books, labeling them "girly" and "traditionally 'boy."

Another mother refers to "in between" books that should appeal to both boys and girls, but while claiming to be an "idealist," still notes a distinct separation between "boy" and "girl" books, stating: "I feel like there are very girly books and very boyish books and 
then there is everything in between and that should all be fair game. *sigh* I guess I am an idealist" $(B 4,2010)$. In this sentence it is unclear if the mother is stating that "all" the books should be "fair game," meaning they can be read by both boys and girls, or if only the "in between" books should be "fair game." In either case, although she presents herself as an "idealist," gender-labeling of young people's reading materials helps construct her worldview.

Bloggers' and commenters' speaking directly against the labeling of books as "girl"- and "boy"- preferred (21 examples). Despite the gendered expectations of educators toward children's reading preferences demonstrated in the sample, examples of resistance are also found. Bloggers and commenters resist the labeling of books as "girl"and "boy"- preferred. The greatest number of examples of resistance to the labeling of books as "girl"- and "boy"- preferred represent the perspectives of parents and focus on not producing gender-based reading lists for boys and girls; not expecting that boys will not want to read books with female protagonists; encouraging children to read whatever they find interesting; and, commenting in relation to experiences of reading with children and seeing that their reading preferences do not follow rigid gender demarcations.

Comments by other adults, designated "miscellaneous" because their roles cannot be determined from the information available, follow the same patterns as those made by parents, but also include 2 very specific comments - one, a reaction to a talk given by Jon Scieszka at the American Library Association conference, and the other, a comment regarding the rigid preservation of social norms relating to masculinity.

The reaction to Jon Scieszka's speech is in the form of a letter, written by an adult female. In the letter, she responds to Scieszka's talk and to the concept behind his "Guys Read" movement, stating that the gender roles Scieszka described do not depict all boys (stating, for example, that not all boys are hockey fans). She also notes that if books are marked or categorized as "guy" books, girls will be less willing to read them, and some boys will still not be interested in them $(B 21,2012)$. This letter represents active resistance to Scieszka's labeling of books as "boy" - preferred, and it also connects gender norms in relation to other activities, (i.e. invoking hockey as an example of a "boy" - preferred sport) to gender-labeling of books.

The other comment, focusing on the rigidity of social norms surrounding masculinity, presents the gender-labeling beginning with insistence on gender-appropriate clothing for baby boys as morphing into the gender-labeling of children's books: It just seems that, around what we currently teach very small children, the rules bend easier for girls
than boys. Baby girls might be dressed in blue overalls, but a baby boy won't be put in pink ones. A 3
year old girl dressing up as a construction worker would get a smile, while a 3 year old boy dressing
up as a princess would be told "oh, don't let your dad see that, ha, ha, ha." And on and on and on. Until
we end up talking about "girl" books and "boy" books as though the books had genders themselves.
(B4, 2010)

In this excerpt the adult female commenter's perception that the taboo against boys' violation of social norms associated with masculinity is stronger than that of girls violating the rules of femininity is also evident. Although this commenter draws a connection between gendered clothing, beginning in infancy, and the gender-labeling of children's books, she discusses the stronger taboo against the violation of social norms associated 
with masculinity only in relation to gendered clothing. Subsequently, the theme of a social taboo against boys reading feminine books will be taken up, discussing the expression of the belief that a child's sex should not influence the child's reading preferences.

Like the commenter's letter to Jon Scieszka described above, a female librarian's comment to a parent in the library represents active resistance to the labeling of books as "girl" and "boy" books. The librarian, upon overhearing a father in the library reprimanding his preschooler son for choosing "girl" books from the shelves, approached him and, upon seeing that the boy had chosen Olivia (Ian Falconer), assured the father that Olivia is everyone's favorite. She also expresses dismay that the father is upset at the choices of such a young child (B7, 2012). This librarian thereby challenges the father's notion that the wellknown Olivia book is for girls, resisting his gender-labeling of the books his son is choosing in the library.

Two comments coded according to resistance to the labeling of books as "girl" and "boy" books are by teachers. One notes that in her 28 years of teaching and her experiences reading with her own children and grandchildren, gender-labeling of books is meaningless and unnecessary. Moreover, she recognizes the taboo against boys reading books that might be considered feminine, expressing her distaste for boy-centered reading lists, which she feels contribute to boys' feeling shame over enjoying reading books that would be considered appropriate for girls. She adds that in her experience of reading aloud with children, the books they chose as their favorites were the ones with the most interesting stories, unrelated to whether the protagonist was male or female $(B 21,2012)$. The teacher here comments on the concept of "boy" books, legitimized through lists of recommended reading for boys, lists which she perceives as causing boys to understand that they are not allowed to read books that would be considered more appropriate for girl readers. The teacher also stresses the importance of story quality as an indicator of whether children will enjoy the story over whether the protagonist is male or female.

The one comment by an author (Lenore Look) relating to resistance to the labeling of books as "girl" and "boy" books highlights an editor's request that she write a "boy" book:

My editor asked me to write a "boy book" like my Ruby Lu books. "Just make him like Ruby, except a boy," she said. But I didn't want to do that. How can you make a boy like a girl? You can't. (B3, 2012)

Here, Look highlights the role of the publishing industry in gender-ing books through requests made of authors. Although she later states, "BTW, Alvin isn't a 'boy book' any more than Ruby Lu is a 'girl book.' If guys limit themselves to reading only about guys ..., they'll miss out on some really fantastic books, including Ruby Lu" (B3, 2012), she nevertheless upholds the notion of inherent differences between girls and boys in describing the impossibility of making "a boy like a girl" (B3).

The one comment by a child, a tween girl (B1 blogger), coded according to resistance to the gender-labeling of books, equates her resistance with feminism:

Gary Paulsen has a reputation of being an author for boys. In fact, my brother is a big fan of Lawn Boy (even though he really doesn't like to read). But, I do not like being told what is a boy book and what is a girl book, I am a feminist, as you probably guessed already. (B1, 2011) 
B1 blogger specifically resists the notion of "boy" and "girl" books, relating it to her stance as "a feminist." She also notes that her brother, whom she characterizes as a reluctant reader, enjoys reading books by Gary Paulsen, whose books are generally perceived as being more appropriate for boys than for girls.

In summary, 72 examples of educators' labeling of books as "girl"- and "boy"preferred are evident among the data, and most of these are by librarians and parents. Moreover, in two cases in which mothers claim to be more balanced in their views, they still rely on rigid differentiation between "boy" books and "girl" books in recommendations for reading. However, 21 examples of resistance to gender labeling are also found, and they range from suggestions, such as doing away with gender-labeled reading lists or encouraging children to read what interests them, to more active opposition, as in the librarian's directly challenging a father's insistence that his three-year-old son not choose "girl" books in the library. Other themes include the following: a social taboo against boys' violating masculine norms that is perceived to be stronger than for girls' violating feminine norms; and the perception that masculine social norms are enforced from the time of infancy (as in, gendered clothing).

Educators' expectations of boys' reading preferences (53 examples). In the data sampled for this study, educators align boys' reading preferences with the following: stories with male protagonists, comics, graphic novels, science fiction, adventure, nonfiction, sports, fantasy, gross humor, stories featuring vehicles, and magazines. Most examples are reading suggestions and reviews of books matching what are perceived to be "boy" preferred categories. The research literature (i.e., Davies \& Brember, 1993; Millard, 1994; McKechnie, 2006; Moss, 2007) on children's reading preferences documents, to some extent, the notion that these categories tend to be boy-preferred. However, some scholars (i.e., Chapman et al., 2007) suggest that children's self-described preferences may differ from that which children perceive to be gender-appropriate. In this sense, the relationship between individual reading preference and social perceptions of children's reading preferences remains unclear. Moreover, the work of Dutro (2003) with African-American male students shows that children can be encouraged, within certain contexts, to step outside gendered reading boundaries.

Librarians account for most of the examples describing boys' reading preferences according to themes perceived to be "boy"-preferred, followed by parents, and teachers. Of the examples representing the perspectives of librarians, 23 are from B3, a blog written primarily with an audience of boys in mind, and the bloggers are two male public librarians working in youth services. A typical example from B3, which is a review of a graphic novel, reads: "If you like high action, plot twist, great artwork, space adventure, green slime and a mouse with a mission, this is definitely the Graphic Novel for you!!!!! Great stuff!!!!!!” (B3, 2010). At times, B3 blogger directly addresses boy readers, as in: "one of your fellow reader guys, Jedi-J.T, wrote a review of the first Barnstormers/Sluggers book" (B3, 2009). Moreover, the reviews are of books the librarians presume would be "boy"-preferred. Overall, in terms of the alignment of boys' reading preferences with texts that are traditionally perceived as "boy" texts, the perspectives of librarians are best represented 
among the data sampled.

Iconic boy books (42 examples). Bloggers and commenters also consistently mention certain books and/or series, called "iconic boy books" in this study, in reference to boys' reading. Books identified as "iconic boy books" are those that are frequently mentioned and almost always mentioned in relation to boy readers. They include the following: Dav Pilkey's Captain Underpants series (19 examples), Jeff Kinney's Diary of a Wimpy Kid series (10), Rick Riordan's Percy Jackson and the Olympians series (9), and Gary Paulsen's Hatchet (4). In this section, Captain Underpants, Diary of a Wimpy Kid, and Percy Jackson and the Olympians will be discussed.

A male school librarian states outright that from what he has seen, most readers of Captain Underpants are boys (B10, 2012). A mother's comment about the Captain Underpants series - "My son absolutely loves Captain Underpants books, and they are the first series of books that he has wanted to read completely independently" $(\mathrm{B} 4,2010)$ - is typical of other comments about the series, in which it is described as a gateway to solo reading for boys (particularly for those who are reluctant readers). However, unlike the example just mentioned, some examples of Captain Underpants disparage it as potty humor unworthy of adult attention and a popular text that should only be used as a catalyst to encourage reluctant reader boys to read better, more serious literature. For example, in the course of criticizing a teacher for discouraging a young boy from reading Captain Underpants, a mother states:

I think Captain Underpants is dreadful with it's [sic] lowest common denominator kind of potty humor, but I would recommend it to a reluctant reader who likes that kind of book. The graphics, the actual kinesthetic appeal to the book, all make it worthy of being read. If a child is reading, I saw [sic] it's a good thing. Lay off the judging. (B4, 2010)

Although the mother, in this statement, is critical of the teacher, she is also critical of the Captain Underpants series, calling it "dreadful," and describing the humor as appealing to the "lowest common denominator."

Like the Captain Underpants series, Jeff Kinney's Diary of a Wimpy Kid series stands out as an iconic boy text. Among the data sampled, it is frequently mentioned as a boy favorite. For instance, a boy, whose review of the book is posted to blog B3 (maintained by male librarians, working in youth services in a public library), writes:

Jeff Kinney really writes funny stuff! (My Nannah doesn't get some of it, but that is okay, because she is a girl.) Greg Heffley is the boy writing the diary about his day to day life. He writes about his family and friends and stuff that happens to him in school. It has lots of funny cartoons in it too. Two of my favorites were about a guy riding a skateboard and the second is about the things you can get away with saying when there is a substitute teacher. I can hardly wait to read the next book about Greg and his brother Rodrick. (B3, 2008)

Notable in this review of the first book in the series is the boy's comments that his "Nannah" (presumably his grandmother) does not understand it "but that is okay, because she is a girl," (B3, 2008), thereby presenting the book as a for-boys-only text. The boy reader's focus on the male protagonist (Greg) and the cartoons reiterate assumptions about boy-preferred themes. 
Boy readers and parents give positive reviews of Diary of a Wimpy Kid. However, a female librarian/mother, B22 blogger, is critical of the series, particularly because of what she sees as a lack of moral character demonstrated by the protagonist - a middle school boy. The one concession she makes, and at the same time comparing the series to Captain Underpants, is that the series can serve as a catalyst for the reading of reluctant boy readers, who would otherwise choose not to read:

When I initially reviewed this book, my main reaction was: Ick [emphasis in original]. As the mother of boys, I imagined my own children exhibiting the unremitting lack of consideration that mars Greg's every action, and it broke my heart to think of a child so devoid of empathy. Doesn't mean I haven't recommended the book. There are some middle grade boys - boys who think fantasy is a ridiculous waste of time, boys who read Calvin \& Hobbes and maybe Captain Underpants - and when I see those guys, I press Diary of a Wimpy Kid into their hands.

This mother/librarian finds Diary of a Wimpy Kid so questionable that she would recommend it only as an option for boys who might otherwise read only comics or Captain Underpants. In this paragraph, the mother/librarian disparages two "iconic boy books," Diary of a Wimpy Kid and Captain Underpants, and, in scorning Calvin and Hobbes, also does not count comics as a valid reading choice for boys.

As with the Captain Underpants series, Diary of a Wimpy Kid, even when presented in a favorable way, is still linked to reluctant boy readers. For example, a mother writes:

Diary of a Wimpy Kid. Definitely! These are the perfect book for such a kid. Just enough text to keep it book-like, but also enough art to keep it visual. Hilariously funny - my husband read them as well, chortling to himself the whole time. Also is a bit naughty and has cool-factor for reading at school. All this and a movie tie-in too...what more could a reluctant reader want? :) My son has also lately been enjoying Zac Power books. I haven't looked at them too closely, but they seem to be more on the action side than the funny side. (B4, 2012)

Referring both to her husband and son's reading of the series, this mother's comments support the notion of the series as an "iconic boy book." In noting that the series is "cool" enough "for reading at school," and there is "a movie tie-in," she adds to the perception that even boys who would not otherwise want to read (or would be embarrassed to be caught reading books) will read the series.

Examples mentioning the Percy Jackson and the Olympians series are primarily written by boys (5), although there are also 3 examples by librarians, and 1 by a parent. The comments written by boys are reviews of books in the series posted on B3, a blog with an intended audience of boy readers and hosted by male public youth services librarians. A typical example reads:

One of my favorite books that I read was the Percy Jackson series. Percy is a teenage boy who is a Greek demigod. He goes to a camp called Camp Half-Blood and trains there for fighting because Percy goes on multiple quests. He meets two friends at Camp Half Blood; Grover and Annabeth. The three friends go on quests everywhere...I liked this series because ther [sic] is action on every page. Plus I never stopped reading Riordan's books [sic]. Rick Riordan is my favorite author. $(\mathrm{B} 3,2012)$

In this review, the boy, noting that one of the books in the series is a "favorite," focuses on the constant "action" in the plot as his main reason for liking the series. He also states that Rick Riordan, the author of the series, is his "favorite author."

A review by a male public youth services librarian (posted to B3) of another book (Grace Lin's Where the Mountain Meets the Moon) with a female protagonist references the 
Percy Jackson series as an incentive to encourage boys to read the series, stating:

Does Minli ever get to change her family's fortune? You'll just have to read to find out!! But I will tell you this - things change in a way Minli could never have predicted!! This is one terrific book, guys! It's not a slam-bang action fantasy like The Lightning Thief but it will keep you turning pages. (B3, 2009)

This comparison to The Lightning Thief, the first book in the Percy Jackson series, in an attempt to entice boy readers to try a book with a female protagonist, supports the iconic status of the Percy Jackson series as a "boy" series.

Among the blog data sampled for this study, there are also a few cases in which girls write reviews of these "iconic boy books" or adults mention them as children's favorites without labeling them "boy" books. For example, a reference to Captain Underpants made by a mother - addressing what she imagines as other parents' frustration with the series as something they hope their children quickly grow out of liking- does not specifically refer to boy readers. However, like the other examples, it refers to the series as a gateway to books that are perceived to be more sophisticated and of higher quality $(B 11,2007)$.

Five references to Diary of a Wimpy Kid and three references to Percy Jackson among the data sampled are by female readers. However, two of the references to Diary of a Wimpy Kid are actually reviews of another series called Dork Diaries, in which Dork Diaries is presented as a sort of "girl" version of Diary of a Wimpy Kid, as in, "I really like Dork Diaries. It's a GREAT BOOK! I like it because it's like Diary of a Wimpy Kid and I like that. It's about a girl named Nikki Maxwell who goes to a new school" (B3, 2011). Reviews of the Percy Jackson series by girl readers are similar to those written by boy readers - positive reviews focusing on the novels' suspenseful, exciting plots.

The discussion of the "iconic boy" series, including Dav Pilkey's Captain Underpants series (19 examples), Jeff Kinney's Diary of a Wimpy Kid series (10), and Rick Riordan's Percy Jackson series (9), described above as "boy" series because of the number of times they are mentioned among the data sampled in reference to boy readers, illustrates educators' insistence on gender-labeling of books, particularly of "boy" books. In that these series are mentioned as "boy" favorites, not only by educators but also by boys themselves, indicates that boys may have internalized the gendered labeling of these books.

Educators' expectation that boys prefer male protagonists and girls prefer female protagonists ( 22 examples). Review of the data provides evidence that educators, including parents, librarians, and teachers, expect boys to prefer male protagonists and girls to prefer female protagonists. They also assume that girls are more likely than boys to read a story featuring a protagonist of the opposite sex. In some cases, the blogger/commenter's statement is an expression of the appropriate audience for a particular book:

Throughout the adventure, Will Parker is a wonderfully flawed hero on which to rest the hopes of mankind. He is often petty and too quick to temper, sometimes childish and even lazy. He is, thus, easy to identify with. A young man will recognize his own flaws in Will (as will a still-seeking adult) even as Will becomes more and more aware of these deficiencies and learns to correct them. (B13, 2009)

In this example, B13 blogger, a father, pinpoints whom he believes to be the book's target audience - "a young man" - and explains why this audience will identify with the book's 
male protagonist. In other cases, a comment speaks to the commenter's previous experience of girls' preference for female protagonists and boys' preference for male protagonists, as in this mother's comment: "Brynn prefers to read books about girls, because she's such a girly-girl, but she will happily read books about boys if they are good. But I'm not sure the opposite is true. My little brother wouldn't read "girl books" no matter what" (B4, 2009). In this comment the perception that the taboo against boys' reading "girl" books is stronger than girls' reading "boy" books is also evident.

Bloggers' and commenters' expressing the belief that a child's sex should not influence the child's reading preferences (15 examples). The greatest number of examples of resistance come from parents, while children and young adults are second. Also represented are one illustrator and two adults whose roles are not able to be determined from the text. Salient among these examples is the notion that a gender neutral approach to young people's reading preferences is particularly important in terms of boys' reading, given that the taboo against boys reading what are perceived to be "girl"-preferred texts is stronger than against girls reading what are perceived to be boy-preferred texts. A blog post on B21 (the blog of a prominent literary magazine focused on reviews of children's literature) written by a mother (who is also founder and president of a library board and informal teacher), illustrates that theme. The mother perceives boys, due to homophobia and a lack of tolerance for boys' behaving in ways that would be considered effeminate, as facing much stricter reading taboos than girls, so that it is much more difficult for boys to read any book that would be considered feminine. In contrast, girls, due to feminism, have a broader range of choices. She mentions classics as an example, stating that no one would have a problem with girls reading Sherlock Holmes, Homer Price, or works by Mark Twain or Robert Louis Stevenson, but boys reading Jane Austen, the Brontës, or Louisa May Alcott, might be ridiculed. The mother's resistance to the gendersegregation of children's reading choices focuses on allowing boys to read books (all classics mentioned in this example) featuring female protagonists, but she also calls for greater general acceptance for both boys' and girls' reading choices, warning against the tendency to gender-label books (B21, 2012).

Another example written by a young adult in Australia, relates her experience working in a bookstore, in which she regularly meets parents who are concerned with purchasing books that are gender-appropriate for their daughters and sons. She offers a composite of her experiences, stating that if she recommends that a parent buy the Percy Jackson series for a girl, the parent will often respond that Percy Jackson is a "boy" book and then ask her to recommend something more appropriate for a girl. Even when she tells the parent that she herself really enjoyed the series, the parent refuses her suggestion and buys something with sparkles - typically girly. She notes parents reacting in a similar manner when she recommends The Sisters Grimm series for a boy. The young woman/bookseller vehemently opposes the notion of "boy" books and "girl" books, expressing how much the parents' rigidly defined gendered conceptions of what their sons and daughters should be reading bothers her. She also actively resists perceptions of the gender-appropriateness of books in recommending (through her work in a bookstore) books to parents that they perceive to be gender-inappropriate for their daughters and sons $(B 21,2012)$. 
Another example is from a much younger child - a boy. Although this example is written by a mother, it is treated here as representing the child's perspective. The example is a mother's description of her young son's enjoyment of a series about fairies; his subsequent realization that the books would be perceived by outsiders as inappropriate for him (as a boy) to read (resulting in his hiding the books before a friend came over to play); his fear of the shaming he might face from other children as a result of having the books in his possession; and his moving beyond the limitations of those expectations. Later, her son resumes his resistant, voracious, and omnivorous reading practices, reading anything he himself deems interesting, regardless of whether or not it would be considered appropriate for a boy. In this example, the strong taboo against boys reading what would be perceived as girl-appropriate books is also evident (B21, 2012).

Educators' not expecting girls to prefer what are perceived to be "girl"preferred texts, or boys to prefer "boy"-preferred texts (13 examples). Another form of resistance to the notion of gendered reading preferences is educators' refusal to expect girls to prefer what are perceived to be "girl"-preferred texts, or boys to prefer "boy"preferred texts. Most of these examples represent parents' perspectives, followed by librarians and teachers. In one example, a mother writes that it would be a shame, if, due to gender-labeling of books, girls would not read classics like The Adventures of Tom Sawyer and Treasure Island, or that boys would not read works by Laura Ingalls Wilder and Louisa May Alcott. She also states that when choosing books to read to her sons when they were young, she took a gender-neutral approach, not focusing on the sex of the protagonists but simply sharing many good stories with them (B21, 2012). The mother expresses dismay over the gendered expectations regarding reading audiences for childhood classics and tells of her own commitment to reading many different stories to her own sons, without presuming them to prefer stories with male characters.

However, even the examples that are resistant, in that the blogger or commenter, for instance, is encouraging children to broaden their reading preferences, can still be gendered in the expectations expressed. For example, a book review by B6 blogger, a male teacher, resists gendered norms of reading by encouraging boys to read the book, but also labels the book as more appropriate for girls than for boys (B6, 2011).

\section{Discussion}

\section{Summary of Findings}

Gendered literacy reflects the gender divisions in society and creates a "safe" way in which to approach young people's reading by conveniently dividing the myriad of possible reading choices for youth into "boy" and "girl" books and themes. Gendered literacy is thereby evident both in terms of reading choices encouraged by literacy educators and in children's reading choices. Gender divisions are also used by creators of young people's reading materials to produce and market gendered materials. This article examines gender-labeling of youth literature as a way in which gender divisions relating to literacy practice are enacted. On the other hand, children's reading choices and choices encouraged by educators, publishers, and creators of children's reading materials are also a means by which notions of gendered literacy are disrupted. Resistance involves the refusal to label texts as "boy" or "girl," adjusting expectations regarding what girls and boys may prefer to 
read, and, more generally, separating the notion of whether a child is male or female from reading preference.

Examining the data sampled and analyzed for this study overall, librarians and parents are the main commenters regarding the gender labeling of children's books and reading preferences. Because librarians and parents are among children's primary literacy educators, gendered literacy as a cultural practice is difficult to disrupt. Nonetheless, resistance to the dominant perceptions of literacy as gendered is also evident.

In terms of patterns of resistance, the most prominent form of resistance to the perception of gendered reading comes from educators in response to the labeling of books as "girl" and "boy" books. Of these resistant comments, most represent the perspectives of parents, followed by adults of undetermined role. Another important form of resistance is expression of the belief that a child's sex does not and/or should not influence their reading preferences. Among these comments, parents are best represented, and children and young adults are second. Another form of resistance represented among the data sampled is educators' not expecting that girls should like what are perceived to be "girl"-preferred texts and that boys should like what are perceived to be "boy"-preferred texts) (13), and as in the other two forms of resistance, parents are the main commenters.

Although what is most evident among the data is the labeling of young people's reading preferences and of texts according to "boy" and "girl," broader issues are also evident. Educators' gender segregation of young people's reading preferences devalues certain text types that are tolerated only as bridge texts to help reluctant boy readers learn to enjoy reading including, for example (and as discussed in the article), the "iconic boy books" Captain Underpants and Diary of a Wimpy Kid, as well as non-fiction, comics, graphic novels, and gross humor.

\section{Recommendations for Practice}

In relation to this study's findings, recommendations for practice include avoiding the labeling of books according to boy/girl, in reading lists and in talking about books with children and young adults. When choosing books to be included in the curriculum, educators can choose materials that are more gender-neutral in terms of their appeal. Because there are a large number of examples relating to educators' perceptions of boys' reading preferences according to certain categories that are considered traditionally malepreferred: stories with male protagonists, comics, graphic novels, science fiction, adventure, non-fiction, sports, fantasy, gross humor, stories featuring vehicles, and magazines and "iconic boy books," it is also recommended that educators broaden their perspectives relating to what boys will enjoy reading.

Educators who work closely with children to foster their literacy development may recognize that they are uniquely positioned to be change agents in regard to encouraging both children and educators to read more broadly and to cross gender barriers. They can do this through blogging; writing reviews of materials for children and young adults; compiling reading lists; serving on book award committees; organizing both virtual and physical displays; selecting and purchasing materials; developing curricula and programs; and influencing those who produce materials for young people. B7 blogger provides a model of how to do this. She is materials selector for the youth services department of a 
major library, blogs about youth literature, reviews materials for youth for major publications, and is the author of an illustrated children's book. She has many acquaintances in the publishing world and attempts to wield influence, as when she pushes for a re-illustrated version of William's Doll or a pink cover for a book in the series, Diary of a Wimpy Kid. In another case, a female librarian commenting on B7 demonstrates how educators may challenge parents' preconceived notions of which materials are suitable for girls versus boys, recounting how, after hearing a father scolding his son for selecting "girl" books, she went over to them and assured the father that Olivia is a book that everyone likes (B7, 2012).

The data suggest that youth reading is gendered. However, the data also indicate that literacy educators can disrupt gendered literacy as a cultural practice. Virtual spaces like the KidLitosphere (or, alternatively, physical spaces) have the potential to facilitate dialogue and debate regarding gendered literacy as a cultural practice. Literacy educators can also disrupt gendered literacy by better equipping themselves to advice readers by branching out and reading things they would not normally read. They can also encourage the forms of resistance identified in the data, including: a refusal to label books as "girl" and "boy" books; the belief that a child's sex does not and/or should not influence their reading preferences; and a refusal to expect that children should like texts that are considered normative in terms of boy and girl-preferred texts.

\section{References}

Bausch, L. S. (2014). Boys will be boys?: Bridging the great gendered literacy divide. Rotterdam: Sense Publishers.

Bem, S. L. (1993). The lenses of gender: Transforming the debate on sexual inequality. New Haven: Yale University Press.

Chapman, M., Filipenko, M., McTavish, M., \& Shapiro, J. (2007). First graders' preferences for narrative and /or information books and perceptions of other boys' and girls' book preferences. Canadian Journal of Education, 30, 531-553.

Conway, J. K. (1974). Perspectives on the history of women's education in the United States. History of Education Quarterly, 14, 1-12.

Davies, J., \& Brember, I. (1993). Comics or stories? Differences in the reading attitudes habits of girls and boys in years 2, 4, and 6. Gender \& Education, 5.

Dutro, E. (2003). "Us like to read football and boy stuff": Reading masculinities, performing boyhood. Journal of Literacy Research, 34, 465-500.

Gilbert, P. (1993). Narrative as gendered social practice: In search of different story lines for language research. Linguistics and Education, 5, 211-218.

Glaser, B. G., \& Strauss, A. L. (1967). The discovery of grounded theory: Strategies for qualitative research. Chicago: Aldine Pub. Co.

Gurian, M. (with Stevens, K.). (2011). Boys \& girls learn differently: A guide for teachers and parents. San Francisco: Jossey-Bass.

Hansot, E., \& Tyack, D. (1988). Gender in American public schools: Thinking institutionally. Signs, 13(4), 741-760. 
Lincoln, Y. S., \& Guba, E. G. (1985). Naturalistic inquiry. Beverly Hills, CA: Sage.

Maynard, T. (2002). Boys and literacy: Exploring the issues. London: Routledge/Falmer.

McKechnie, L. E. F. (2006). "Spiderman is not for babies" (Peter, 4 years): The "boys and reading problem" from the perspective of the boys themselves. Canadian Journal of Information and Library Sciences, 30(1/2), 57-67.

Millard, E. (1994). Developing readers in the middle years. Buckingham: Open University Press.

Millard, E. (1997). Differently literate: Gender identity and the construction of the developing reader. Gender \& Education, 9(1), 31-48. doi:10.1080/ 09540259721439

Millard, E. (2003). Gender and early childhood literacy. In Handbook of early childhood literacy (pp. 22-33). Eds. N. Hall, J. Larson, \& J. Marsh. London: Sage.

Monaghan, J. E. (1994). Gender and textbooks: Women writers of elementary readers, 1880-1950. Publishing Research Quarterly, 10, 28-46.

Moss, G. (2007). Literacy and gender: Researching texts, contexts and readers. London: Routledge.

Orellana, M. F. (1995). Literacy as a gendered social practice: Tasks, texts, talk, and take-up. Reading Research Quarterly, 30, 674-708.

Organisation for Economic Co-operation and Development. (2014). PISA 2012 Results: What students know and can do - Student performance in mathematics, reading and science (Volume I, Revised edition, February 2014), PISA, OECD Publishing. Retrieved from http://www.oecd.org/pisa/keyfindings/pisa-2012-results-volume-i.htm

Richardson, H. (2011, August 25). Why boys trail further behind girls at GCSE top grades. BBC News online. Retrieved from http://www.bbc.co.uk/news/education-14664916

Rowan, L., Knobel, M., Bigum, C., \& C. Lankshear. (2002). Boys, literacies and schooling: The dangerous territories of gender-based literacy reform. Buckingham, England: Open University Press.

Sanford, K. (2005/2006). Gendered literacy experiences: The effects of expectation and opportunity for boys' and girls' learning. Journal of Adolescent \& Adult Literacy, 49, 302-315.

Sax, L. (2005). Why gender matters: What parents and teachers need to know about the emerging science of sex differences. New York: Broadway Books.

Smith, M. W., \& Wilhelm, J. D. (2002). "Reading don't fix no Chevys”: Literacy in the lives of young men. Portsmouth, NH: Heinemann.

VIDA: Women in Literary Arts (2014). VIDA count: Children's literature. Retrieved from http://www.vidaweb.org/vida-count-childrens-literature/http://www.vidaweb.org/vidacount-childrens-literature/

Vygotsky, L. S. (1978). Mind in society: Development of higher psychological processes. Eds. Cole, M., John-Steiner, V., Scribner, S., \& Souberman, E. Cambridge: Harvard University Press. 